\title{
A breathtaking chemokine
}

Allergic asthma is a chronic inflammatory lung disease that is thought to be driven by $\mathrm{T}$ helper $2\left(\mathrm{~T}_{\mathrm{H}} 2\right)$ cells, but our understanding of the mechanisms responsible for $\mathrm{T}$ cell recruitment and activation in the allergic lung remains limited. A new study in Nature Medicine now shows that $\mathrm{CX}_{3} \mathrm{C}$-chemokine receptor $1\left(\mathrm{CX}_{3} \mathrm{CR} 1\right)$ and its ligand, $\mathrm{CX}_{3} \mathrm{C}$-chemokine ligand 1 ( $\left.\mathrm{CX}_{3} \mathrm{CL} 1\right)$, exacerbate allergic airway disease by promoting the survival of effector T cells in the inflamed lung.

Previous studies showed that the expression of $\mathrm{CX}_{3} \mathrm{CL} 1$ increases in asthmatic lungs following allergen exposure; therefore, the authors explored the functions of the $\mathrm{CX}_{3} \mathrm{CL} 1-\mathrm{CX}_{3} \mathrm{CR} 1$ axis during allergic airway inflammation in mice.

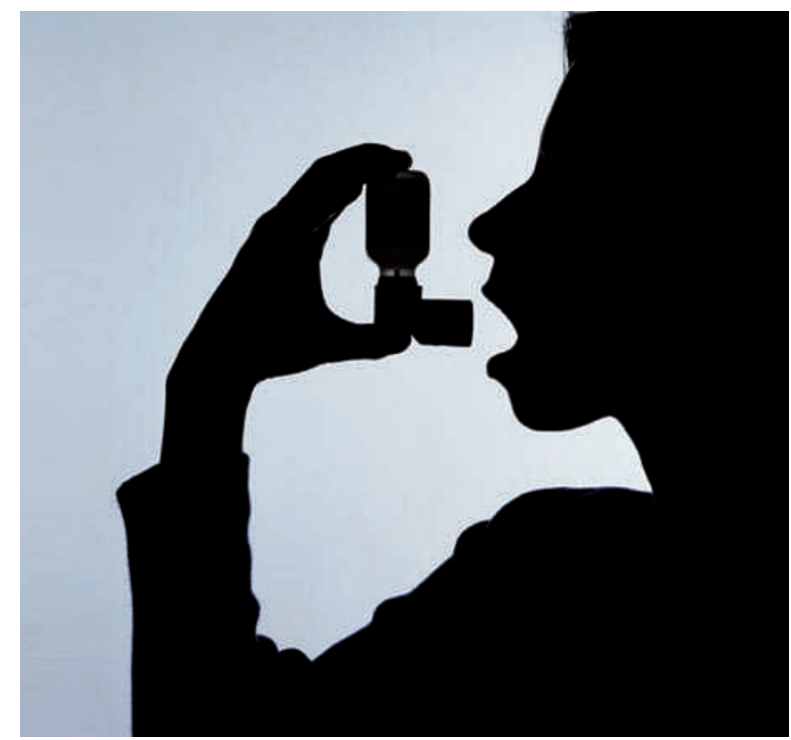

They found that in various models of allergic airway inflammation, $\mathrm{CX}_{3} \mathrm{CR} 1$-deficient mice developed less severe airway disease than wildtype controls. This was characterized by reduced airway hyperreactivity and mucus secretion, fewer inflammatory lung infiltrates and lower levels of $\mathrm{T}_{\mathrm{H}}$ 2-type cytokines. Wild-type mice treated with $\mathrm{CX}_{3} \mathrm{CR} 1$-blocking antibodies or the $\mathrm{CX}_{3} \mathrm{CL} 1$ antagonist FKN-AT before allergen challenge also developed less severe airway disease. Importantly, intranasal administration of FKN-AT was also effective therapeutically in mice with pre-established airway inflammation.

The authors showed that few $\mathrm{T}$ cells from naive mice expressed $\mathrm{CX}_{3} \mathrm{CR} 1$, but up to one-third of $\mathrm{T}_{\mathrm{H}} 2$ cells in the inflamed airways expressed this chemokine receptor. $\mathrm{CD} 4^{+} \mathrm{T}$ cells purified from draining lymph nodes of allergen-sensitized $\mathrm{CX}_{3} \mathrm{CR} 1$-deficient mice produced similar levels of $\mathrm{T}_{\mathrm{H}}$ 2-type cytokines to those from wild-type mice. However, only transfer of wild-type $\mathrm{CD} 4^{+} \mathrm{T}$ cells and not $\mathrm{CX}_{3} \mathrm{CR} 1$-deficient $\mathrm{T}$ cells could restore airway inflammation to wild-type levels in $\mathrm{CX}_{3} \mathrm{CR} 1$-deficient mice. Furthermore, if wild-type allergen-specific $\mathrm{T}_{\mathrm{H}} 2$ cells were treated with FKN-AT before transfer, they could no longer promote increased airway inflammation in $\mathrm{CX}_{3}$ CR1-deficient mice.

Competition assays revealed that $\mathrm{CX}_{3} \mathrm{CR} 1$ was not necessary for the differentiation of $\mathrm{T}_{\mathrm{H}} 2$ cells or for their recruitment to the inflamed lung following allergen challenge. However, compared with wild-type T cells, $\mathrm{CX}_{3} \mathrm{CR} 1$-deficient $T$ cells showed increased rates of apoptosis in the inflamed lung, and in vitro, $\mathrm{CX}_{3} \mathrm{CL} 1$ was shown to promote the survival of wild-type but not $\mathrm{CX}_{3} \mathrm{CR} 1$-deficient $\mathrm{T}_{\mathrm{H}} 2$ cells. Expression of $\mathrm{CX}_{3} \mathrm{CR} 1$ also increased the survival of allergen-specific $\mathrm{T}_{\mathrm{H}} 1$ cells that were transferred to the inflamed lung, but $\mathrm{CX}_{3} \mathrm{CR} 1$ did not increase $\mathrm{T}_{\mathrm{H}} 2$ cell survival in resting or inflamed popliteal lymph nodes.

Finally, the authors showed that $\mathrm{CX}_{3}$ CR1-deficient T cells that were transfected with the anti-apoptotic protein B cell lymphoma 2 (BCL-2) were maintained in inflamed lungs at similar frequencies to wild-type cells. Furthermore, BCL-2-transfected $\mathrm{CX}_{3} \mathrm{CR} 1$-deficient $\mathrm{T}_{\mathrm{H}} 2$ cells could promote airway inflammation in $\mathrm{CX}_{3}$ CR1-deficient mice as effectively as wild-type $\mathrm{T}_{\mathrm{H}} 2$ cells. These data highlight a previously unappreciated role for the $\mathrm{CX}_{3} \mathrm{CL} 1-\mathrm{CX}_{3} \mathrm{CR} 1$ axis in promoting allergic airway inflammation; the authors suggest that intranasal delivery of $\mathrm{CX}_{3} \mathrm{CL} 1$ antagonists could be an effective new therapy for patients with corticosteroidresistant asthma.

Yvonne Bordon

ORIGINAL RESEARCH PAPER Mionnet, C. et al. CX3CR1 is required for airway inflammation by promoting $T$ helper cell survival and maintenance in inflamed lung. Nature Med. 16, 1305-1312 (2010) FURTHER READING Lloyd, C. M. \& Hessel, E. M. Functions of $T$ cells in asthma: more than just $\mathrm{T}_{\mathrm{H}} 2$ cells. Nature Rev. Immunol. 12, 838-848 (2010) 